of the atmosphere as to enable it to quench, in so short a distance, so vast a body of sound? As I stood upon the deck of the Irene, pondering this question, I became conscious of the exceeding power of the sun beating against my back and heating the objects near me. Beams of equal power were falling on the sea, and must have produced copious evaporation. That the vapour generated should so rise and mingle with the air as to form an absolutely homogeneous mixture, I considered in the highest degree improbable. It would be sure, I thought, to streak and mottle the atmosphere with spaces, in which the air would be in different degrees saturated, or it might be displaced, by the vapour. At the limiting surfaces of these spaces, though invisible, we should have the conditions necessary to the production of partial echoes, and the consequent waste of sound.

Curiously enough, the conditions necessary for the testing of this explanation immediately set in. At 3.15 P.M. a cloud threw itself athwart the sun, and shaded the entire space between us and the South Foreland. The production of vapour was checked by the interposition of this screell, that already in the air being at the same time allowed to mix with it more perfectly; hence the probability of improved transmission. To test this inference the steamer was turned and urged back to our last position of inaudibility. The sounds, as I expected, were distinctly though faintly heard. This was at 3 miles' distance. At $3 \frac{3}{4}$ miles we had the guns fired, both point blank and elevated. The faintest thud was all that we heard, but we did hear a thud, whereas we had previously heard nothing, either here or threequarters of a mile nearer. We steamed out to $4^{\frac{1}{7}}$ miles, when the sounds were for a moment faintly heard, but they fell away as we waited; and though the greatest quietness reigned on board, and though the sea was without a ripple, we could hear nothing. We could plainly see the steam-puffs which announced the beginning and the end of a series of trumpet-blasts, but the blasts themselves were quite inaudible.

It was now 4 P.M., and my intention at first was to halt at this distance, which was beyond the sound range, but not far beyond it, and see whether the lowering of the sun would not restore the power of the atmosphere to transmit the sound. But after waiting a little, the anchoring of a boat was suggested; and though loth to lose the anticipated revival of the sounds myself, I agreed to this arrangement. 'Two men were placed in the boat, and requested to give all attention so as to hear the sound if possible. With perfect stillness around them, they heard nothing. They were then instructed to hoist a signal if they should hear the sounds, and to keep it hoisted as long as the sounds continued.

At 4.45 we quitted them and steamed towards the South Sand Head lightship. Precisely fifteen minutes after we had separated from them the flag was hoisted. The sound, as anticipated, had at length succeeded in piercing the body of air between the boat and the shore.

On returning to our anchored boat we learned that when the flag was hoisted the horn sounds were heard, that they were succeeded after a little time by the whistle sounds, and that both increased in intensity as the evening advanced. On our arrival of course we heard the sounds ourselves.

The conjectured explanation of the stoppage of the sounds appeared to be thus reduced to demonstration, but we pushed the proof still further by steaming farther out. At $5^{\frac{3}{4}}$ miles we halted and heard the sounds. At 6 miles we heard them dis. tinctly, but so feebly that we thought we had reached the limit of the sound range. But while we waited the sound rose in power. We steamed to the Varne buoy, which is $7 \frac{3}{4}$ miles from the signal station, and heard the sounds there better than at 6 miles distance.

Steaming on to the Varne lightship, which is situated at the other end of the Varne shoal, we hailed the master, and were informed by him that up to 5 P.M. nothing had been heard. At that hour the sounds began to be audible. He described one of them as "very gross, resembling the bellowing of a bull," which very accurately characterises the sound of the large American steam whistle. At the Varne lightship, therefore, the sounds had been heard towards the close of the day, though it is $12^{3}$ miles from the signal station.

What is the full meaning of this result? Imagine a man in an anchored boat at 2 P.M. at a distance of 2 miles from the Foreland, and suppose him possessed of instruments which would enable him to measure the growing intensity of the sound. Applying the law of inverse squares, to carry the sound to six times the distance, its intensity at 2 miles would have to be augmented
36 times. But the Varne lightship is more than 6 times 2 miles from the Foreland. Supposing no absorption or partial reflection to occur, the observer would have found that by the lowering of the sun the sound at his position had at $6 \mathrm{P} . \mathrm{M}$. risen to more than forty-fold the intensity which it possessed at 2 P.M. In reality the an mentation was still greater.

(To be continued.)

\section{BIRMINGHAM NATURAL HISTORY AND MICROSCOPICAL SOCIETY}

AT the annual soirce, held on Tuesday, December I6, 1873 , celebrating the sixteenth year of the existence of the society, Mr. W. R. Hughes, F.L.S., the president, gave, at the request of the committee, an address on "The recent Marine Excursion made by the Society to Teignmouth." After alluding to the apt and graceful remarks of his predecessor in office (Rev. H: W. Crosskey, F.G.S.) twelve months ago, on the advantages of the study of Natural History, and then describing the preliminary arrangements in connection with the excursion which have already been detailed in NATURE, vol. viii. pp. 334 and 469, Mr. Hughes stated that upwards of 20 menbers of the society, including several ladies, proceeded from Birmingham and assembled at the headquarters at Teignmouth on Monday, September $\mathbf{r}$, on which day the dredging operations commenced on board the yacht $R u b y$ with satisfactory results. These were carried on during the week, and have already been described in NATURE; the principal feature being the capture of the pedunculate form of Antedon rosaceus (Comatula rosacea), the rosy feather star, in. cluding representatives of I 2 genera of Echinodermata and about 40 species of Hydrozoa and Polyzoa, the last of which had been mounted and presented to the society by his friend and colleague, Mr. A. W. Wills, to whom the Society were also indebted for lifelike drawings of the Antedon in various stages of development.

Mr. Hughes then proceeded to speak of the moral of the marine excursion. So far as he was informed it was the first of its kind that had been undertaken by any society carrying on its operations in an inland district like Birmingham, far removed from the sea, and that point was in itself notewortly, and might contribute to raise the status of the society and cause its example to be followed by others of a kindred nature. He thought it was pretty well agreed among the members that the excursion was attempted properly, and on the whole carried out successfully. The members who took part in it had been stimulated and encouraged in their project by the hearty and unanimous way in which it was adopted by others whose studies lay in different airections, by praise from NATURE, that most cultivated of scientific serials, and by "good words" from the local press. The results might not have satisfied all. Circumstances rendered the absence of many old supporters of the society unavoidable. It was planned a little too late in the season, and many of the microscopic animals they dredged had played their part in the great problem of life, and empty cells alone remained where many a delicate and beautiful organism had spread its feathery plumes "in the dark unfathomed caves of ocean." Too much time was devoted to the dredging, and not sufficient for subsequent investigation of the proceeds. Still the members had enjoyed the rare opportunity of examining many beautiful marine animals under the microscope which they could not have hoped for at home. And the excursion had done much to promote exchange of thought and friendliness among those taking part in it. Doubtless if a similar one were planned in 1874 the members would profit by the experience of the late one, and Mr. Hughes commended such to the consideration of the committee, and suggested that the members should make it the subject of their annual holiday, especially as ladies were now for the first time admissible as members. The President stated he could not close his remarks to an assembly composed of naturalists and those who had evinced a taste in their pursuits, without alluding to the fact that must have impressed most of them, viz. : that the study of marine zoology had in these days attained an interest second to that of no other branch of natural history, and that the exist. ence and habits of the denizens of "the great and wide sea" were discussed as familiarly in the newspapers of the day as the events of social and political life. As further evidence, $\mathrm{Mr}$. Hughes alluded to the record, almost surpassing any story in the "Thousand and One Nights" contained in that most charming of books "The Depths of the Sea," of the researches in deepsea dredging, by Prof. Wyville Thomson, F.R.S., and Dr. 
Carpenter, F.R.S., refuting the old theories of the non-existence of animal life at great depths, and bringing to light (with others) animals such as Pentacrinus wyville-thomsoni and Bathycrinzis gracilis, pedunculate star-fishes allied to the Concatulla, from 2,435 fathoms, whose very existence was unsuspected, and who were supposed "in the lapse of ages to have been worsted in the struggle for life." And following these investigations came the exploring expedition of H.M.S. Challenger, the most important mission of its kind that Great Britain had ever engaged in, from whence we now and then got stray tidings of yet more remarkable animals, -animals of comparatively high organisation, allied to the lobster, dredged up from 2,000 fathoms : in one individual, a gigantic amphipodal crustacean, "the eyes of the creature extended in two great facettic lobes over the whole of the anterior part of the cephalo-thorax, like the eyes AEglina among Trilobites" (NATURE, vol. vii. p. 388). In another, Deidamia leptodactyle, there were no traces whatever of eyes of sight or their pedicels (NATURE, vol. viii. p. 52). Further, from the enormous depth of 3,000 fathoms, or nearly $3 \frac{1}{2}$ statute miles, " a depth which does not appear to be greatly exceeded in any part of the ocean," have been taken a tube-building annelid, its tube formed of the gritty matter which occurs but sparingly in the clay at the bottom, affording, in fact, as Prof. Wyville Thomson remarks, "conclusive proof that the conditions of the bottom of the sea to all depths are not only such as to admit of the existence of animal life, but are such as to allow of the unlimited extension of the distribution of animals high in the zoological series, and closely in relation with the characteristic faunæ of shallower zones (NATURE, vol. viii. p. 53).

Contemporaneously with these expeditions and what would appear to be not an inappropriate sequitur, marine aquaria of extensive size, and constructed on scientific principles, had been established in some of our principal towns, thus affording a new source of enjoyment and an intellectual gratification to the people - that of the examination of living marine animals as they exist "in the depths of the sea" -and combining with this in some instances a source of pecuniary benefit to the promoters. The public interest in these establishments seemed so great that the arrival of the octopus had attracted almost as much attention as the visit of a foreign emperor, and the death of the porpoise was mourned as a national calamity.

In conclusion the president said he hoped he had said something suggested by the recent marine excursion to interest the members in marine zoology. For his own part he could say that the little attention he had been able to devote to it had been a most acceptable relief to official duties (as Treasurer of the Borough), always laborious and responsible, and at the same time it had brought him in contact with fellow-workers in natural history from whose friendship and kindly intercourse he had derived the most lasting pleasure.

Mr. Hughes ventured to express his opinion that a Marine Aquarium, if constructed properly and managed efficiently-for instance like that beautiful one at the Crystal Palace under the direction of his friend, Mr. W. Alford Lloyd, who had done more for the advancement of public aquaria than any man livingwould be most acceptable to Birmingham, where the great Priestley carried on his scientific researches, and in 1773 obtained the Copley medal of the Royal Society for the discovery of the mutual dependence of plants and animals on each other-the grand principle of all aquaria. It occurred to him after much thought, and as a successful student of marine aquaria for many years, that no greater attraction or means of intellectual recreation for the working classes and their neighbours in the mining districts could be devised, because it would be so utterly different from any other exhibition now existing, and so suitable as a relief and mental refreshment for those in crowded courts to whom the sea was but a name. It was indisputable that "the sea and its living wonders" had irresistible fascination to us far away from it. The peculiar central inland position of Birmingham would be highly advantageous by allowing ready and rapid modes of conveyance of rare animals from almost any part of the coast. $\mathrm{He}$ commended the project to the earnest consideration of the many wealthy and intellectual men in the town, and could not help believing and hoping-although his views as a naturalist might be sanguine-that Birmingham would sooner or later possess a marine aquarium worthy of it, and follow the example of London, Brighton, Liverpool, Manchester, Plymouth, and other large towns, which, besides others on the Continont, hod already taken the matter up.
We understand that Mr. Hughes' suggestion has been acted u pon, and that an influential committee has since been appointed to make inquiries with the view to the promotion of an efficient marine aquarium for Birmingham.

\section{SCIENTIFIC SERIALS}

Astronomische Nachrichten, No. I,969, Jan. 9.-This number contains a paper by Prof. Spoerer on M. Faye's theory of solar spots. He refers to M. Faye's statement that spots are below the surface of the sun, and to his reliance on his treatment of Carrington's observations ; for if a spot be observed for two or more revolutions its distance from the limb can be calculated on the assumption that the spot is on the surface of the sun. Should, however, the observed plan of the spot not agree with the calculated position, the assumption will be that the spot is below or above the vurface of the sun. Prof. Spoerer informs us that, on the whole, his observations show that the observed distance from the limb of the sun are too great; this he ascribes to the effect of refraction altering the position of the sun's limb to a greater degree than that of the spot.-On the identity of Coggia's Comet of Nov. IO, with Comet 1818 I, by Prof. Weiss. In this paper the author gives the elements of Coggia's comet as lately determined, together with the recorded observations of Comet I8I8I. from which he considers the two comets to be identical.-In a second paper by Prof. Weiss he gives elements calculated on a parabolic orbit and on two elliptic orbits of 55.82 and 6.9775 years respectively, being on the assumption in the first case thai one revolution has happened since 1818 , and in the other that eight have taken place.-Observations on variable stars, by G. 'T. G. Schmidt. From observations up to the end of 1873 , given at length in his paper, we extract the epochs of maxima and minima of the following stars :-

\begin{tabular}{|c|c|c|c|c|c|}
\hline \multirow{5}{*}{$\begin{array}{l}\text { Mira Ceti } \\
\text { S Scorpii } \\
\text { R Scorpii } \\
\text { R Bootis } \\
\text { R Virginis } \\
\text { S Coronre }\end{array}$} & about & $\begin{array}{l}\text { Max. } \\
\text { May } 25\end{array}$ & & $\begin{array}{l}\text { Min. } \\
\text { Jan. } 30 .\end{array}$ & $1873, \mathrm{mag}$ \\
\hline & avout & Sept. I3, & mag. Io & - & \\
\hline & ," & Aug. 27, & mag. 10.8 & - & ,", \\
\hline & ", & Sept. I 5 , & 一 & - & ," \\
\hline & ", & July 27, & 一 & May 13 & \\
\hline \multirow{2}{*}{\multicolumn{2}{|c|}{$\begin{array}{l}\mathrm{R} \text { Leonis } \\
\mathrm{R} \text { Leporis }\end{array}$}} & $\begin{array}{l}\text { July } 6 \text {, } \\
\text { Max. }\end{array}$ & Min. & \multirow{4}{*}{\multicolumn{2}{|c|}{ Period $404^{\prime} 7$ days. }} \\
\hline & & May I $\delta$ & $\overline{\operatorname{Tan}} \cdot \overline{29}$ & & \\
\hline$\gamma$ Bура & & $\begin{array}{l}\text { Oct. } 5 \\
\text { May 13 }\end{array}$ & June 16 & & \\
\hline RScl & $\ldots$ & $\left\{\begin{array}{l}\text { July } 9 \\
\text { Sept. } 20 \\
\text { Nov. } 4\end{array}\right.$ & $\begin{array}{l}\text { Aug. } 2 \text { I } \\
\text { Oct. I3 } \\
-\end{array}$ & & \\
\hline
\end{tabular}

Wilhelm Schur gives an opposition ephemeris for Arethusa. The opposition happening Jan. $2 \mathrm{I}$, the $\mathrm{R}$. A. being then

$$
\text { 8.2.52.78 and Dec. }+4 \cdot 1 \cdot 54
$$

The fourth line of the spectrum of the nebula in Orion, by D'Arrest. The author refers to a note on this line by Dr. Vogel in Astron. Nach., No. 1963, mentioning the fact that the fourth line of the nebula coincided with $\mathrm{H} \gamma$, and goes on to mention that this line was known to Huggins in $\mathbf{1 8 6 4}$, and by Capt. Herschell in 1868 , and was brought to the notice of the Royal Society in 1872 by Huggins. Its wave-length he gives as 4343 . The author also mentions a peculiarity in the spectrum of B. Durchm $+22^{\circ} 4203 .-$ Mr. J. Birmingham states in a note that he believes that 252 Schjellcrup has disappeared, and he thinks this star a remarkable variable.

Medizinische fahrbücher: k.k. Gesellsch. d. Aerzte: Vienna, 1873, Heft 3 and 4 . - The last two issues of this quarterly journal for 1873 contain the following papers of scientific interest :Researches into the minute structure of the Tendon, by Arnold Spina, with an illustration; the Nerves of the Knee-joint in the Rabbit, by Dr. C. Nicoladoni (with a figure) ; contributions to the Anatomy of the Human Bladder, by Dr. Gustav Jurie Quarantine in Cholera, a report to the International Medical Congress, by Dr. Oser.

\section{SOCIETIES AND ACADEMIES LONDCN}

Zoological Society, Jan. 20.-Prof. Newton, F.R.S., vicepresident, in the chair.-Mr. Sclater exhibited two skulls of Baird's Tapir (Tapirzs bairtli) received from Mr. Constantine 